\title{
Evaluation of collared anteaters (Tamandua tetradactyla) presented in a wildlife health reference center of São Paulo state, Brazil
}

\author{
Agda Maria Bernegossi ${ }^{1}$, Sheila Canevese Rahal ${ }^{*}$ (1), Alessandra Melchert ${ }^{2}$, Carlos Roberto Teixeira ${ }^{\text {, }}$ \\ Fábio Henrique Lima ${ }^{1}$, Raphael Duarte Medeiros ${ }^{3}$ \& Aline Alves da Silva ${ }^{3}$ \\ ${ }^{1}$ Universidade Estadual Paulista, Departamento de Cirurgia e Anestesiologia Veterinária, Faculdade de Medicina \\ Veterinária e Zootecnia, Botucatu, SP, Brazil \\ ${ }^{2}$ Universidade Estadual Paulista, Departamento de Clínica Veterinária, Faculdade de Medicina Veterinária e \\ Zootecnia, Botucatu, SP, Brazil \\ ${ }^{3}$ Arquitetos Urbanistas, Mitra, Araraquara, SP, Brazil \\ *Corresponding author: Sheila Canevese Rahal,e-mail: sheilacr@fmvz.unesp.br
}

BERNEGOSSI, A. M., RAHAL, S. C., MELCHERT, A., TEIXEIRA, C. R., LIMA, F. H., MEDEIROS, R., SILVA, A. Evaluation of collared anteaters (Tamandua tetradactyla) presented in a wildlife health reference center of São Paulo state, Brazil. Biota Neotropica. 18(1): e20170440. http://dx.doi.org/10.1590/1676-0611-BN-2017-0440

\begin{abstract}
Deforestation and road construction have inflicted negative effects on wildlife populations. To contribute to the comprehension and preservation of wildlife species, this study aimed to evaluate collared anteater presented to a reference center located in São Paulo state, Brazil. Furthermore, the locations where the animals were most frequently found were determined. Data on collared anteaters (Tamandua tetradactyla) examined at the Center for Medicine and Research in Wild Animals (CEMPAS) were evaluated retrospectively for a period of 13 years. A total of 46 collared anteaters was examined, comprised of 14 males, 10 females, and 22 without identifying information. On average, adult males weigh $4.41 \mathrm{~kg}$ while adult females weigh $4.95 \mathrm{~kg}$. The most common admission circumstance was vehicular strikes (36.96\%), followed by dog bites (21.74\%); $23.91 \%$ were considered clinically healthy. Animal outcomes were $36.96 \%(n=17)$ reintroduced, $34.78 \%(n=16)$ fatalities, $15.22 \%(n=7)$ transferred to other institutions, and $6.52 \%(n=3)$ escaped from the enclosure; and 6.52\% $(\mathrm{n}=3)$ presented no medical record information. The collared anteaters were found mainly in the municipal areas of Botucatu (21.73\%), São Manuel (17.39\%), Lençóis Paulista (6.52\%), and Bauru (4.34\%), with SP-300 being the main highway associated with the occurrences. In conclusion, the main cause of lesion in the collared anteaters evaluated in this study was vehicular strike that that led to death. However, including all collared anteaters at least half of them had a positive outcome.
\end{abstract}

Keywords: Wild animal, highway, clinical evolution, anteater.

\section{Avaliação de tamanduás-mirins (Tamandua tetradactyla) atendidos em um centro de referência de animais selvagens do Estado de São Paulo, Brasil}

Resumo: O desmatamento e a construção de estradas têm promovido uma série de problemas à fauna. Visando contribuir com informações que podem ser usadas na compreensão e preservação das espécies, o trabalho teve por objetivo avaliar tamanduás-mirins atendidos em um centro de referência localizado no Estado de São Paulo, Brazil. Foram avaliados retrospectivamente dados referentes a tamanduás-mirins (Tamandua tetradactyla), que foram trazidos ao Centro de Medicina e Pesquisa em Animais Selvagens (CEMPAS), durante um período de 13 anos. De um total de 46 tamanduás-mirins atendidos, 14 foram machos e 10 foram fêmeas, e 22 não possuíam identificação quanto ao sexo. Em média, os machos adultos pesaram 4,41 kg, enquanto as fêmeas adultas pesaram 4,95 kg. Com relação à circunstância que levou ao atendimento, as mais importantes foram o atropelamento $(36,96 \%)$ e a mordedura de cães $(21,74 \%)$, sendo que $23,91 \%$ foram considerados clinicamente saudáveis. No tocante à evolução dos casos, $36,96 \%(n=17)$ foram reintroduzidos, $34.78 \%(n=16)$ foram a óbito, $15,22 \%(n=7)$ foram transferidos para outras instituições, $6,52 \%(n=3)$ evadiram do recinto e $6,52 \%(n=3)$ não há informação. Os animais foram provenientes principalmente dos municípios de Botucatu (21,73\%), São Manuel (17,39\%), Lençóis Paulista (6,52\%) e Bauru (4,34\%), sendo a SP-300 a principal rodovia relacionada as ocorrências. Foi possível concluir que dos tamanduás-mirins avaliados a principal causa de lesão foi o atropelamento, que teve por evolução o óbito; porém ao se incluir os tamanduás-mirins saudáveis e demais, ao menos metade evoluíram positivamente.

Palavras-chave: Animal selvagem, rodovia, evolução clínica, tamanduá. 


\section{Introduction}

Tamandua tetradactyla, also known as the collared anteater or lesser anteater, is a mammal that belongs to the Xenarthra magnorder, Mymecophagidae family (Naugher 2004; Hayssen 2011), and is considered an arboreal and terrestrial opportunist (Naugher 2004; Medri et al. 2006). In South America, the species is distributed over the northern and central regions (Hayssen 2011). The species is found in all types of biomes in Brazil, but in the Pantanal it lives mainly at the edge of the forest (Desbiez \& Medri 2010; Miranda 2014).

The collared anteater has a head-body length of approximately 47 to $77 \mathrm{~cm}$, body mass from 2 to $7 \mathrm{~kg}$, with a long prehensile tail used as a fifth limb (Nowak 1999; Naugher 2004; Medri et al. 2006), and tubular mouth without teeth (Naugher 2004; Haysen 2011). The color of the fur is usually pale tan or golden, and may or may not have a black vest or collar (Hayssen 2011; Miranda et al. 2014). Color variation and morphological differences may occur according to territorial origin; for example, in Brazil, individuals from the northern portion of the country present a darker color than those from the Atlantic Forest (Miranda 2014).

Feeding can occur on the ground or on trees and consists of termites, ants, honey and bees (Medri et al. 2006; Smith 2007; Miranda et al. 2014; Gallo et al. 2017). The collared anteater has a well-developed sense of smell that assists in locating food and compensates for poor vision and hearing (Smith 2007; Miranda 2014). Feeding items adhere to the sticky substance secreted by the submaxillary glands on the tongue, which is cylindrical and $40 \mathrm{~cm}$ long (Smith 2007).

Deforestation and road construction have caused negative effects on wildlife populations, a fact observed in Amazon state where animals, especially mammals of the order Pilosa, have been struck by vehicles (Costa 2014). This has also occurred in the central region of Brazil (Miranda 2014); furthermore, there are reports of animals injured or killed in the south and southeast of the country (Vieira 1996; Prada 2004; Cherem et al. 2007; Costa, 2011; Orlandin et al. 2015; Preuss 2015).

Aiming to contribute to the comprehension and preservation of wildlife species, the purpose of this study was to evaluate collared anteaters presented to a reference center located in São Paulo state. In addition, the locations where the animals were most frequently found were determined.

\section{Materials and Methods}

This study was approved by Ethics Committee for Animal Care and Use of the School of Veterinary Medicine and Animal Science, UNESP Botucatu (no. 33/2016-CEUA).

Data in relation to collared anteaters (Tamandua tetradactyla) examined at the Center for Medicine and Research in Wild Animals (CEMPAS) of the School of Veterinary Medicine and Animal Science, UNESP Botucatu, Brazil, were evaluated retrospectively for a period of 13 years (2003-2016).

Identifying data on collared anteaters (sex, body mass), municipal area where animal rescue occurred, circumstances of admission, time of hospitalization, and case outcome (reintroduction, place of destination, death) were analyzed. A map of São Paulo state enabled estimation of the locations where the largest numbers of animals were found.

Adescriptive analysis was made of the admission circumstances, case outcome and hospitalization duration. Spearman correlation test was used to assess the correlation between sex (male/female) and circumstances of admission, number of hospitalization days and case outcome (reintroduction, place of destination, death, escape from the enclosure). The correlation between survival/death and cause of hospitalization, number of hospitalization days and case outcome (reintroduction, place of destination, death, and escape of the enclosure) were also evaluated by Spearman correlation test. The Spearman correlation coefficient was interpreted as follows: $r$ 0.1-0.3 = weak; 0.4-0.7 = moderate; 0.8-1.0 =strong (Bhuyan et al. 2016). Incomplete data in the medical record that created inconsistency were excluded from statistical analysis.

The comparison of the collared anteater divided into survival versus death groups was carried out using Mann-Whitney test for non-parametric data (cause of hospitalization and sex), and unpaired $t$ test for parametric data (days until outcome). For comparison of the animals allocated into two groups according to sex (males vs. females), the Mann-Whitney test for nonparametric data (cause of hospitalization, outcome and days until outcome), and unpaired $t$ test for parametric data (body mass) were used The animals that survived were also allocated into groups according to the disease to compare days until outcome by one-way analysis of variance (ANOVA). Differences were considered significant at $\mathrm{P}<0.05$.

\section{Results}

A total of 46 collared anteaters was examined, comprised of 14 males, 10 females and 22 without identifying information. On average, adult males weigh $4.41 \mathrm{~kg}(\mathrm{SD}=1.83)$ while adult females weigh $4.95 \mathrm{~kg}(\mathrm{SD}=1.53)$. As to the admission circumstances: $36.96 \%(n=17)$ of the collared anteaters had been struck by vehicles; $23.91 \%(\mathrm{n}=11)$ were considered clinically healthy; $21.74 \%(n=10)$ had been bitten by dogs; $4.34 \%(n=2)$ had suffered burns; $6.52 \%(\mathrm{n}=3)$ were hospitalized due to other causes (gastroenteritis, eye injury, prostration); and for the remaining $6.52 \%(n=3)$, there was no information in the medical record (Fig. 1). The days of hospitalization associated with admission circumstances were: from 0 to 300 days (Mean $\pm \mathrm{SD}=48.73 \pm 92.64$ ) for those struck by vehicles; from 1 to 300 days for animals bitten by dogs (Mean $\pm \mathrm{SD}=28.56 \pm 46.33$ ); from 8 to 10 days for those that suffered burns (Mean $\pm \mathrm{SD}=9 \pm 1.41$ ); from 1 to 105 days for those hospitalized due to other cause (Mean $\pm \mathrm{SD}=35.67 \pm 60.04$ ); from 1 to 9 days (Mean $\pm \mathrm{SD}=2.4 \pm 2.84$ ) for healthy animals

In relation to animal outcomes, $36.96 \%(\mathrm{n}=17)$ were reintroduced, $34.78 \%$ $(\mathrm{n}=16)$ died, $15.22 \%(\mathrm{n}=7)$ were transferred to other institutions, and 6.52\% $(n=3)$ escaped from the enclosure; there was no information in the medical record of the remaining $6.52 \%(\mathrm{n}=3)$. Among the anteaters that had been struck by vehicles, $47.60 \%(\mathrm{n}=8)$ died, $23.53 \%(\mathrm{n}=4)$ were transferred to other institutions, $23.53 \%(\mathrm{n}=4)$ were reintroduced, and $5.88 \%(\mathrm{n}=1)$ escaped from the enclosure. All the anteaters that had suffered burns died $(n=2)$. Considering the collared anteaters that had been bitten by dogs, the outcomes were: $40 \%(n=4)$ reintroduced, $30 \%(n=3)$ fatalities, $20 \%(n=2)$ transferred to

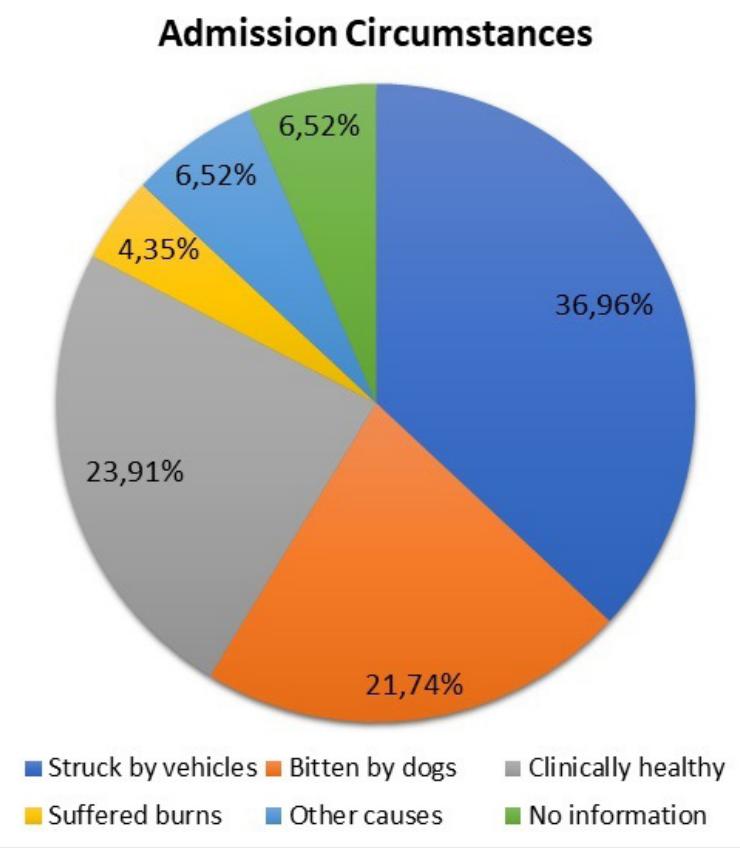

Figure 1. Admission circumstances of collared anteaters presented in a wildlife health reference center. 
other institutions, and $10 \%(\mathrm{n}=1)$ without information in the medical record. Among the animals considered clinically healthy anteaters, $72.73 \%(\mathrm{n}=8)$ were reintroduced, $9.09 \%$ (1) escaped from the enclosure, and $9.09 \%(\mathrm{n}=1)$ died; for the remaining $9.09 \%(n=1)$, there was no information. As to the animals hospitalized due to other causes $(n=3)$, the outcomes were one death $(33.33 \% ; \mathrm{n}=1)$, one reintroduction and one transference to another institution. Of those animals without information about admission circumstances, $67.7 \%(n=2)$ died, while the outcome of $33.33 \%(n=1)$ was not registered.

The statistical analysis did not show correlation between sex (male/female) and cause of hospitalization $(\mathrm{r}=-0.026 ; \mathrm{P}=0.9032)$, days of hospitalization $(\mathrm{r}=0.043 ; \mathrm{P}=0.8483)$ or outcome of the cases $(\mathrm{r}=-0.257 ; \mathrm{P}=0.2374)$. No correlation was observed between survival/death and cause of hospitalization $(\mathrm{r}=0.3635 ; \mathrm{P}=0.195)$, days of hospitalization $(\mathrm{r}=0.1365 ; \mathrm{P}=0.3948)$, or $\operatorname{sex}(r=0.2390, P=0.2606)$. There was a significant correlation between survival/death and case outcome $(r=0.8914, \mathrm{P}=0.0001)$.
No statistical differences were detected between survival versus death groups or sex $(\mathrm{P}=0.3503)$, body mass $(\mathrm{P}=0.3402)$ and days of hospitalization $(\mathrm{P}=0.1043)$. However, a significant difference occurred in relation to cause, given that every animal that died had been struck by a vehicle $(\mathrm{P}=0.0287)$. No statistical differences were detected between groups according to sex (males vs. females) and cause of hospitalization $(\mathrm{P}=0.9314)$, outcome $(\mathrm{P}=0.7088)$, days until outcome $(\mathrm{P}=0.8718)$ or body mass $(\mathrm{P}=0.3402)$.

The collared anteaters were found mainly in the municipal areas of Botucatu (21.73\%; n=10), São Manuel (17.39\%; n=8), Lençóis Paulista $(6.52 \%$; n=3), and Bauru (4.34\%; $n=2)$. Only one collared anteater was found in each of the following municipal areas: Agudos, Areiópolis, Assis, Avaí, Bofete, Cabrália Paulista, Cerqueira César, Conchal, Pardinho, and Tupã, (2.17\%). There was no information in the medical record of 13 (28.26\%) animals.

The São Paulo state map indicated that the main highway associated with the findings of these animals was SP-300 (Fig. 2).
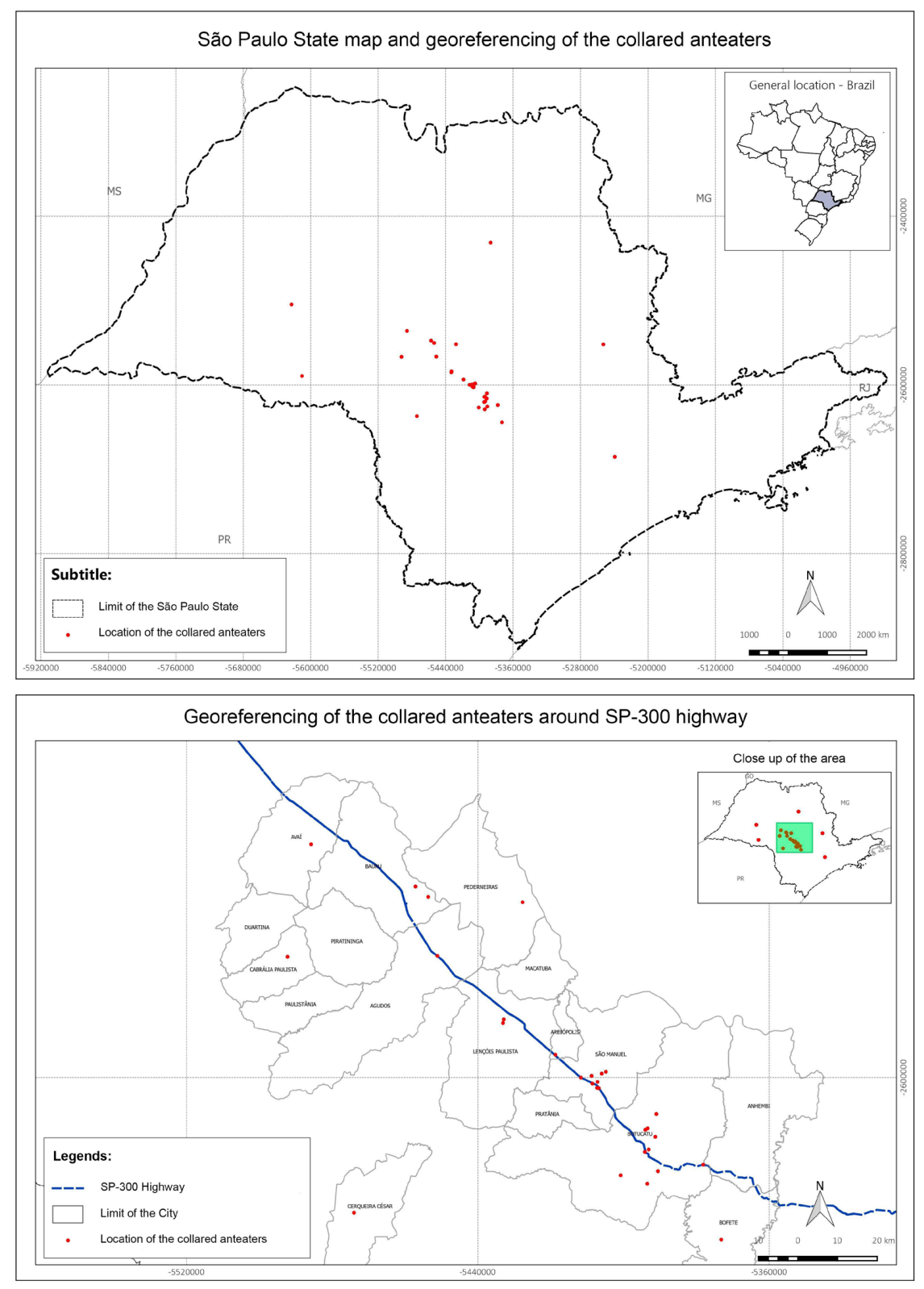

Figure 2. Map of São Paulo State showing the places where collared anteaters were found. Note that the SP-300 was the main highway associated with the occurrences. 


\section{Discussion}

Due to their broad distribution, the collared anteaters are ranked as Least Concern on the red list of Threatened Species by the IUCN (International Union for Conservation of Nature and Natural Resources) (Miranda et al. 2014). Nevertheless, the reduction of the species is associated with vehicular accidents, fire, habitat loss, hunting and dog attacks (Medri et al. 2006; Hayssen 2011; Miranda 2014). In the present study, except for the collared anteaters that were considered clinically healthy, vehicular strikes and dog bites were the main causes of admission.

One of the reasons for these findings may be related to the solitary habits of collared anteaters that are found together only during the mating season (Naugher 2004; Rezende et al. 2013; Miranda et al. 2014). This makes them more vulnerable to being attack by other animals, despite taking refuge in tree-holes, as well as in ground nests (Nowak 1999; Smith 2007). Moreover, although captive collared anteaters may be active during the day, their nocturnal to diurnal-crepuscular activities are the most common in nature (Hayssen 2011), which corroborates their being hit by cars. In addition, these animals present slow-moving and placid behavior (Smith 2007; Miranda 2014).

The present study has found a significant correlation between survival/death and case outcome, given that most of the animals that died had been struck by vehicles. Thus, injury severity and fatality risk are very high when collared anteaters are struck by vehicles. In addition, the distribution of locations where the animals were found on the São Paulo state map revealed the importance of the SP-300 highway. Several authors have reported the negative consequences of constructing highways or roads on wildlife, since they affect, directly and indirectly, the populations of numerous species of wildlife, constituting an important cause of habitat loss and fragmentation (Cherem et al. 2007; Costa 2014; Miranda 2014). In studies related to the number of mammals species hit by cars on roads and highways in Brazil, the following percentages were found related to the collared anteaters: $1.4 \%, 1.51 \%, 5.4 \%, 8.6 \%, 10.12 \%$, and $21 \%$ respectively, in relation to six roads in the northeast region of São Paulo state (Prada 2004), five highways in western Santa Catarina (Orlandin et al. 2015), three roads in Santa Catarina state (Cherem et al. 2007), Brasilia-Campinas highway (Vieira 1996), the highway BR-282 located in the west of Santa Catarina state (Preuss 2015). and BR 101 road along of the cost of Santa Catarina state (Costa 2011). Thus, more studies are necessary to determine the roads impact in wild animal populations in each State of Brasil.

Although there was no correlation between sex and cause of hospitalization, days of hospitalization, or outcome of the cases, it should be considered that only 24 out of the 46 collared anteaters had their sex identified in the medical record (14 males and 10 females). There are citations that the estrous cycle of collared anteaters lasts approximately 42 days, whereas the gestation period may be 85-190 days (Hayssen 2011; Rezende et al. 2013). In general, the female gives birth to one offspring per year (Miranda et al. 2014), then carries the newborn on her back for several months, or even for a year (Smith 2007; Miranda 2014). Thus, the death of collared anteaters could cause significant loss of species.

On the other hand, it is important to emphasize that including all healthy and unhealthy or injured collared anteaters $(n=46)$ presented for examination, 17 were reintroduced (36.95\%) and seven were sent to another institution (15.21\%), indicating that at least half of the cases had a positive outcome. The reintroductions were performed with the authorization of the competent authorities, and was done in fragments of forest near the region where the animal was found, or in places registered by the Ministry of the Environment.

In conclusion, the main cause of lesion in the collared anteaters evaluated in this study was vehicular strike that that led to death. However, including all collared anteaters at least half of them had a positive outcome.

\section{Acknowledgements}

The authors are grateful to CNPq (National Council for Scientific and Technological Development - PIBIC and Process 300710/2013-5), the National Institute of Science and Technology of Wildlife Science Center (WSC).

\section{Author Contributions}

Agda Maria Bernegossi - Substantial contribution in the concept and design of the study, Contribution to data collection

Sheila Canevese Rahal - Substantial contribution in the concept and design of the study

Alessandra Melchert - Contribution to data analysis and interpretation

Carlos Roberto Teixeira, Fábio Henrique de Lima - Contribution to critical revision, adding intelectual content

Raphael Duarte Medeiros, Aline Alves da Silva - Contribution to manuscript preparation

\section{Conflicts of Interest}

The authors declare that they have no conflict of interest related to the publication of this manuscript.

\section{References}

BHUYAN, D., DUA, N. \& KOTHARI, T. 2016. Epidemiology and biostatistics: fundamentals of research methodology. Open J. Psychiatry Allied Sci. 7:87-93.

CHEREM, J.J., KAMMERS, M., GHIZONI-J, I.R. \& MARTINS, A. 2007. Mamíferos de médio e grande porte atropelados em rodovias do Estado de Santa Catarina, sul do Brasil. Biotemas. 20:81-96.

COSTA, L.S. 2011. Levantamento de mamíferos silvestres de pequeno e médio porte atropelados na BR-101, entre os municípios de Joinville e Piçarras, Santa Catarina. Biosci. J. 27:666-672.

COSTA, A.M. 2014. Desafios para a conservação da fauna Amazônica. In Tratado de animais selvagens (Z.S. Cubas, J.C.R. Silva \& J.L. Catão-Dias, eds). Roca, São Paulo, p.2370-2381.

DESBIEZ, A.L.J. \& MEDRI, Í.M. 2010. Density and habitat use by giant anteaters (Myrmecophaga tridactyla) and southern anteaters (Tamandua tetradactyla) in the Pantanal wetland, Brazil. Edentata. 1:4-10.

GALlO, J.A., ABBA A.M., ELIZALDE, L., DI NUCCI, D., RÍOS, T.A. \& EZQUIAGA, M.C. 2017. First study on food habits of anteaters, Myrmecophaga tridactyla and Tamandua tetradactyla, in the southern limit of their distribution. Mammalia. 81:601-604.

HAYSSEN, V. 2011. Tamandua tetradactyla (Pilosa: Myrmecophagidae). Mamm. Species. 43:64-74.

MEDRI, I.M., MOURÃO, M.G. \& RODRIGUES, F.H.G. 2006. Ordem Xenarthra. In Mamíferos do Brasil N.R. Reis, A.L. Peracchi, W.A. Pedro \& I.P. Lima, eds). Londrina, Paraná, p.71-99

MIRANDA, F. 2014. Cingulata (tatus) e Pilosa (preguiças e tamanduás), in: Tratado de animais selvagens. (Z.S. Cubas, J.C.R. Silva \& J.L. Catão-Dias, eds). Roca, São Paulo, p.707-722.

MIRANDA, F., FALLABRINO, A., ARTEAGA, M., TIRIRA, D.G., MERITT, D.A. \& SUPERINA, M. 2014. Tamandua tetradactyla. The IUCN Red List of Threatened Species 2014: e.T21350A47442916. http://dx.doi.org/10.2305/ IUCN.UK.2014-1.RLTS.T21350A47442916.en. Accessed 15 August 2017.

NAUGHER, K.B. 2004. Tamanduas (Myrmecophagidae). In Grzimek's Animal Life Encyclopedia, Mammals II (M.C. McDade, ed.). Gale Group, Farmington Hills, p.170-179.

NOWAK, R.M. 1999. Order Xenarthra. In: Walker's Mammals of the World. Johns Hopkins University Press, Baltimore, p. 156-157.

ORLANDin, E., PIOVESAN, M., FAVRETTO, M.A., D’AGOStini, F.M. Mamíferos de médio e grande porte atropelados no Oeste de Santa Catarina, Brasil. Biota Amazonia. 5:125-130. 
PRADA, C.S. 2004. Atropelamento de vertebrados silvestres em uma região fragmentada do nordeste do Estado de São Paulo: quantificação do impacto e análise dos fatores envolvidos. $\mathrm{PhD}$ thesis, Universidade Federal de São Carlos, São Carlos.

PREUSS, J.F. 2015. Composição e caracterização da fauna de mamíferos de médio e grande porte atropelados em trecho da BR-282, oeste do Estado de Santa Catarina. Unoesc. \& Ciênc. 6:179-186.

REZENDE, L.C., GALDOS-RIVEROS, A.C., MIGLINO, M.A. \& FERREIRA, J.R. 2013. Biology of reproduction in the sloth and anteater: a review. Rev. Bras. Reprod. Anim. 37:354-359.
SMITH, P. 2007. Tamandua tetradactyla, in: FAUNA Paraguay Handbook of the Mammals of Paraguay. http://www.faunaparaguay.com/tamanduatetradactyla. html. Accessed 25 February 2016.

VIEIRA, E.M. 1996. Highway mortality of mammals in central Brazil. Ciênc. Cult. 48:270-272.

Received: 05/09/2017

Revised: 21/12/2017

Accepted: 23/12/2017

Published online: 08/02/2018 